\title{
Keefektivan Beauveria bassiana (Bals.) Vuill. Isolat Indigenous Pagaralam Sumatera Selatan Pada Media Beras Terhadap Larva Plutella xylostella Linn. (Lepidoptera: Yponomeutidae)
}

\author{
YULIA PUJIASTUTI, ERFANSYAH, DAN SITI HERLINDA
}

Jurusan Hama dan Penyakit Tumbuhan Fakultas Pertanian Universitas Sriwijaya

Jalan Raya Palembang-Prabumulih, Km 32 Inderalaya, Ogan Ilir 30662

(diterima September 2005, disetujui Februari 2006)

\begin{abstract}
Effectiveness of Beauveria bassiana (Bals.) Vuill. isolate Pagaralam South Sumatera on rice media against Plutella xylostella Linn. (Lepidoptera : Yponomeutidae) Larvae. The objective of study was to investigate the effectiveness of Beauveria bassiana isolate cultured in half-ripe rice media against third-instar larvae of Plutella xylostella. The research used 10 isolates consisted of 4 isolates that were originnally collected from Pagaralam i.e. $\mathrm{PD}_{1}$ (isolated from $P$. xylostella cadaver), $\mathrm{PD}_{2}, \mathrm{PD}_{8}, \mathrm{PD}_{9} \mathrm{~B}$ (from Crysodeixis chalcites cadaver), and 6 isolates from other areas as comparison, i.e. $\mathrm{CCW}_{3}$ (from Crysodeixis chalcites cadaver), $\mathrm{BBL}$ (from Hypothenemus hampei cadaver), CH (from Conomorpha cramerella cadaver), CPJW (from $H$. hampei cadavi), WC (from Nilaparvata lugens cadaver), and WSJT (from Leptocorixa acuta cadaver). The parameters that were measured were mortality of larvae, time of death and behaviour of larvae after application. Result of the test showed that B. bassiana isolated from L. acuta (WSJT isolate) caused the highest mortality i.e. $73.34 \%$, with the highest spore density $5.6 \times 10^{7}$ spore $\mathrm{ml}^{-1}$ (in half-rice media) and $3.0 \times 10^{7}$ spore $\mathrm{ml}^{-1}$ (GYA media). The lowest $\mathrm{LT}_{50}$ was 19.27 hours, and was obtained from the application of $\mathrm{PD}_{9} \mathrm{~B}$. After application of $\mathrm{B}$. bassiana, the behaviour of larvae was slightly change from a healthy one to less in consuming of food and then die.
\end{abstract}

KEY WORDS: Effectivity, Plutella xylostella, Beauveria bassiana, $\mathrm{LT}_{50}$

\section{PENDAHULUAN}

Plutella xylostella Linn. (Lepidoptera: Yponomeutidae) merupakan hama penting sayuran Brassicaceae (Andrahennadi \& Gillott 1998). Hama ini merupakan hama yang bersifat oligofagus yang memakan tanaman dari famili Brassicaceae. Perkembangan yang singkat dengan keperidian yang tinggi menyebabkan hama ini sangat berbahaya terhadap produk pertanian famili
Brassicaceae (Ulmer et al. 2001). Kerusakan yang ditimbulkan oleh hama ini sangat besar. Charleston \& Kfir (2000) menyatakan bahwa P. xylostella dapat menyebabkan kerugian lebih dari 90\% dan diperkirakan lebih dari 1 milyar US dolar pertahun biaya yang harus dikeluarkan untuk mengendalikan hama ini. Di Kanada, ledakan hama ini mengakibatkan 10 juta petani mengalami kerugian (Ulmer et al. 2001). Pada tahun 
1997, serangan hama ulat kubis mengakibatkan terjadinya gagal panen di pulau Lombok (Oka 1998).

Adanya resistensi P. xylostella terhadap berbagai insektisida membuat hama ini sulit untuk dikendalikan, walaupun pengendalian dengan varietas tahan telah dilaksanakan (Andrahennadi \& Gillot 1998). Adanya dampak negatif penggunaan pestisida sintetik dan peningkatan resistensi $P$. xylostella memaksa kita untuk mencari alternatif pengendalian yang lebih baik, yaitu pemanfaatan pestisida hayati, berbagai predator, parasitoid dan cendawan entomopatogen yang dapat digunakan sebagai pengganti pestisida sintetik yang mampu menekan populasi hama sasaran nya (STBPTPH 1998). Pengendalian dengan menggunakan cendawan entomopatogen merupakan pengendalian yang ramah lingkungan karena tidak memiliki efek samping sehingga sangat baik untuk dikembangkan dan diterapkan (Ulmer et al. 2001). B. bassiana merupakan cendawan tanah yang sangat umum di temukan di seluruh dunia. Sampai saat ini telah dikenal lebih dari 750 spesies cendawan entomopatogen dari sekitar 100 generasi cendawan (Cloyd 2003). Beras merupakan salah satu media yang cukup baik untuk pertumbuhan B. bassiana, karena beras mengandung unsur pokok karbohidrat (STBPTPH 1998). Pada penelitian sebelumnya telah berhasil diisolasi beberapa isolat cendawan B. Bassiana dari daerah dataran tinggi Pagar Alam Sumatera Selatan. Cendawan tersebut diisolasi dari larva P. Xylostella dan Chrysodeixis chalcites (Pujiastuti 2004). Untuk itu, perlu dilakukan perbanyakan isolat cendawan tersebut sehingga dapat dimanfaatkan sebagai agens hayati. Penelitian ini bertujuan untuk menyeleksi keefektivan B. Bassiana Pagaralam yang ditumbuhkan pada media beras setengah masak terhadap larva instar tiga P. Xylostella. Sebagai pembanding keefektivan cendawan asli Pagaralam, maka digunakan isolat $B$. Bassiana asal daerah lainnya.

\section{BAHAN DAN METODE}

Serangga uji P. Xylostella diambil dari daerah sentra sayuran dataran rendah di Talang Buruk dan Sukarela, Kota Palembang Sumatera Selatan. Pembiakan massal serangga uji dan perbanyakan cendawan dilaksanakan di Laboratorium Entomologi dan Fitopatologi Jurusan Hama dan Penyakit Tumbuhan Fakultas Pertanian Universitas Sriwijaya di Inderalaya. Penelitian ini dilaksanakan dari bulan Januari 2004 sampai dengan Februari 2005. Selama penelitian suhu dalam ruangan berkisar antara $25,5-31,0^{\circ} \mathrm{C}$ dan kelembaban udara relatif $67-80 \%$.

\section{Pembiakan Serangga Uji}

Serangga uji yang diambil dari lapangan dikelompokkan berdasarkan fase perkembangannya, dan dipelihara di laboratorium pada wadah plastik besar (diameter $20 \mathrm{~cm}$, tinggi $30 \mathrm{~cm}$ ) yang ditutup dengan kain gas sampai menjadi 
imago. Di atas wadah plastik yang berisi imago digantung larutan madu 10\% pada kapas sebagai pakannya yang diikat dengan benang. Serangga dimasukkan ke dalam wadah plastik yang telah berisi daun caisin dan dibiakkan sampai menjadi pupa. Pakan larva diganti setiap hari. Tanaman caisin juga dimasukkan ke dalam kurungan plastik $(20 \mathrm{~cm}$ x 20 $\mathrm{cm} \times 50 \mathrm{~cm}$ ) yang berisi imago sebagai tempat imago meletakkan telur. Tanaman diganti setiap hari untuk mencegah pembusukan yang dapat menghambat perkembangan larva dan kehidupan imago.

\section{Pemeliharaan Tanaman Uji}

Pada pot yang telah diisi tanah bercampur pupuk kandang ditanam dua benih tanaman caisin. Tanaman caisin disiram sampai tanaman cukup besar. Tanaman tersebut digunakan untuk pakan larva P. xylostella.

\section{Perbanyakan Koloni Beauveria bassiana (Bals.) Vuill}

Isolat B. Bassiana yang digunakan dalam percobaan seperti tercantum pada tabel 1. Media yang digunakan untuk perbanyakan cendawan B. bassiana ialah media GYA (Glukosa Yeast Agar). Komposisi media untuk volume 250 $\mathrm{ml}$ adalah glukosa $2,5 \mathrm{~g}$, Yeast extract $1 \mathrm{~g}$, Agar 5 g, tepung jangkrik 1,25 g selanjutnya disterilkan dalam autoclave. Media yang telah steril tersebut dituang ke dalam cawan petri (diameter $9 \mathrm{~cm}$ ). Setelah media dingin lalu ditanam konidia cendawan dengan menggunakan jarum ose yang diambil dari isolat yang telah disediakan. Media tersebut disimpan di lemari isolat selama dua minggu. Setelah itu isolat diperbanyak dengan menggunakan $50 \mathrm{~g}$ media beras setengah masak yang telah disterilkan dengan menggunakan autoclave selama \pm 20 menit. Media disimpan di lemari

Tabel 1. Isolat-isolat Beauveria bassiana (Balsamo) Vuillemin asal berbagai inang dan lokasi

\begin{tabular}{llll}
\hline \hline No. & Kode Isolat & Inang & Daerah Asal \\
\hline 1 & $\mathrm{PD}_{1}{ }^{*}$ & Plutella xylostella & Pagaralam \\
2 & $\mathrm{PD}_{2}{ }^{*}$ & Chrysodeixis chalcites & Pagaralam \\
3 & $\mathrm{PD}_{8}{ }^{*}$ & Chrysodeixis chalcites & Pagaralam \\
4 & $\mathrm{PD}_{9}{ }^{*}$ & Chrysodeixis chalcites & Pagaralam \\
5 & $\mathrm{BBL}$ & Hypothenemus hampei & Bogor \\
6 & $\mathrm{WC}$ & Nilaparvata lugens & Cipanas \\
7 & $\mathrm{CCW}{ }_{3}$ & Chrysodeixis chalcites & Ciherang \\
8 & $\mathrm{CH}$ & Spodoptera litura & Bogor \\
9 & $\mathrm{CPJW}$ & Chrysodeixis chalcites & Jawa Tengah \\
\hline
\end{tabular}

Keterangan : *) Isolat indigenous Pagaralam 
isolat selama tiga minggu sampai semua permukaan media beras tertutup oleh hifa. Cendawan hasil perbanyakan ini digunakan sebagai bahan percobaan.

\section{Aplikasi Cendawan Beauveria bassiana pada Larva Plutella xylostella}

Spora B. bassiana yang telah tumbuh pada media beras setengah masak diambil dengan menggunakan jarum ose, dilarutkan ke dalam $100 \mathrm{ml}$ air steril, kemudian di tambahkan perekat (Agristick) 2,5 $\mu$ ldan diaduk hingga tercampur merata di atas shaker agar sporanya tidak menggumpal. Jumlah konidia dihitung dengan menggunakan haemo cytometer di bawah mikroskop dengan perbesaran 400x. Pengenceran dengan air dilakukan untuk mendapatkan konsentrasi $10^{3}$ konidia per $\mathrm{ml}$. Sebagai pembanding digunakan kontrol yaitu tanpa ada penambahan spora $B$. bassiana. Pengaplikasian dilakukan dengan cara meneteskan larutan sebesar $10 \mu \mathrm{l} \mathrm{ke}$ tubuh larva P. xylostella. Pada setiap perlakuan digunakan 20 larva uji dan diulang sebanyak 3 kali.

\section{Analisis Data}

Data yang diperoleh dari penelitian ini disusun dalam bentuk tabulasi dan dianalisis secara deskriptif. Pengamatan meliputi :
Persentase Mortalitas Larva $\boldsymbol{P}$. xylostella dalam waktu 24 jam dan 48 jam

Persentase mortalitas larva (P) dihitung dengan rumus :

$$
\mathrm{P}=\frac{\text { Jumlah larva yang mati }}{\text { Jumlah seluruh larva }} \times 100 \%
$$

\section{Lethal Time $\left(\mathrm{LT}_{50}\right)$}

Penghitungan nilai $\mathrm{LT}_{50}$ didapat dengan menganalisa probit waktu kematian larva yang telah diberi perlakuan dengan menggunakan program SAS.

\section{Perilaku Larva Plutella xylostella} Linn. (sejak aplikasi hingga menjelang kematian)

Pengamatan dilakukan dengan cara mencatat langsung setiap aktivitas yang dilakukan larva dimulai dari saat penetesan larutan isolat sampai larva tersebut mati.

\section{Daya Kecambah Spora Masing- masing Isolat Sebelum Aplikasi (pada media beras setengah masak) dan Sesudah Aplikasi (Glukosa Yeast Agar)}

Perkecambahan spora dikaji berdasarkan viabilitas spora. Pengamatan viabilitas spora dilakukan sebelum perlakuan dengan interval waktu 6 jam sekali selama 24 jam. Penghitungan viabilitas spora dikaji berdasarkan viabilitas spora. Pengamatan viabilitas spora di- 
lakukan sebelum perlakuan dengan interval waktu 6 jam sekali selama 24 jam. Penghitungan viabilitas spora dilakukan dengan menggunakan rumus menurut Gabriel dan Riyanto (1989) dalam Rasminah et al., (1997), yaitu:

$$
V=\frac{g}{g+u} \times 100 \%
$$

$$
\begin{aligned}
V & =\text { Viabilitas spora } \\
g & =\text { Jumlah spora yang berkecambah } \\
u & =\text { Jumlah spora yang tidak berke- } \\
& \text { cambah }
\end{aligned}
$$

\section{Kerapatan Spora Masing-masing} Isolat Sebelum Aplikasi (ditumbuhkan pada media beras setengah masak) dan Sesudah Aplikasi (GYA)

Penghitungan kerapatan spora dilakukan dengan menggunakan rumus menurut Gabriel dan Riyanto (1989) dalam Rasminah et al. (1997) yaitu:

$$
\mathrm{C}=\frac{t}{n \cdot 0,25} \times 10^{6}
$$

$\mathrm{C}=$ Kerapatan spora per ml larutan

$T=$ Jumlah total spora dalam kotak sampel yang diamati

$n=$ Jumlah kotak sampel

$0.25=$ Faktor koreksi dari penggunaan kotak sampel skala kecil dalam haemocytometer.

\section{HASIL DAN PEMBAHASAN}

\section{Persentase Mortalitas Larva Plutella xylostella}

Pengamatan dikelompokkan pada asal isolat yaitu asli Pagaralam Sumatera Selatan dan non Pagaralam. Isolat Pagaralam, dengan sumber inokulum $C$. Chalcites menunjukkan tingkat mortalitas tertinggi, yaitu 5 persen setelah larva uji ditetesi suspensi cendawan dalam waktu

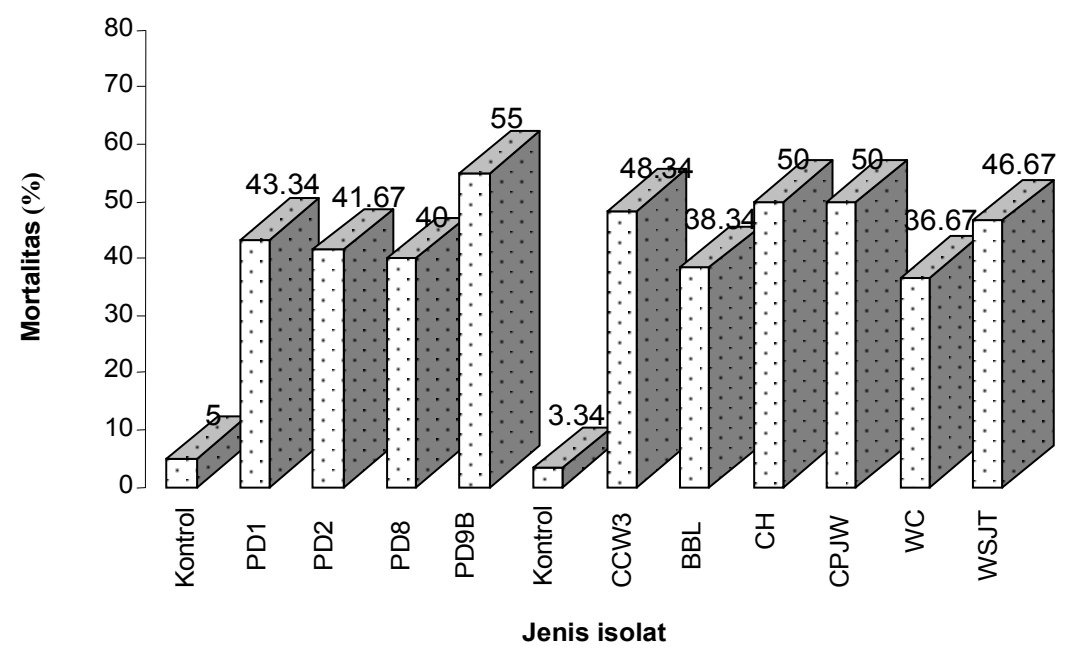

Gambar 1. Mortalitas larva Plutella xylostella L. pada perlakuan berbagai isolat Beauveria bassiana (Bals.) Vuill. 24 jam setelah aplikasi 
24 jam. Isolat dari daerah non Pagar Alam yang merupakan isolat asal $S$. Litura dan C. Chalcites, menunjukkan tingkat mortalitas sampai dengan 50\% setelah 24 jam perlakuan. Hasil tersebut menunjukkan bahwa meskipun sumber isolat cendawan berasal dari spesies yang berbeda dengan serangga uji, mortalitas yang dihasilkannya tetap tinggi. Hal ini mengindikasikan bahwa pertumbuhan cendawan pada media beras setengah masak cukup baik sehingga daya patogenisitasnya masih cukup tinggi yaitu mematikan sebanyak 50\% serangga uji (Gambar 1).

Pada pengamatan 48 jam setelah perlakuan, isolat $\mathrm{PD}_{9} \mathrm{~B}$ (asal Pagaralam, sumber inokulum $C$. chalcites) menunjukkan hasil terbaik diantara isolat-isolat yang berasal dari Pagaralam dengan tingkat kematian 58,34\%. Isolat WSJT (asal non Pagaralam, sumber inolulum L. acuta) menyebabkan tingkat mortalitas paling tinggi yaitu 73,34 persen (Gambar 2).

\section{Lethal Time $\left(\mathrm{LT}_{50}\right)$}

$\mathrm{LT}_{50}$ adalah waktu yang dibutuhkan agar kematian populasi larva uji mencapai 50\%. Hasil pengamatan menunjukkan bahwa setiap isolat mempunyai nilai $\mathrm{LT}_{50}$ yang berbeda-beda. Hal ini sangat erat hubungannya dengan daya penetrasi dari masing-masing isolat terhadap tubuh larva. Dari Tabel 2 dapat ditentukan bahwa nilai $\mathrm{LT}_{50}$ untuk isolat yang berasal dari non Pagaralam berkisar antara 23,26-66,66 jam, dengan nilai $\mathrm{LT}_{50}$ yang terbaik terdapat pada isolat $\mathrm{CH}$ dengan sumber inokulum S. Litura. Sementara itu, $\mathrm{LT}_{50}$ untuk isolat yang berasal dari Pagaralam berkisar antara 19,27-44,81 jam, dimana nilai $\mathrm{LT}_{50}$ yang terendah terdapat pada isolat $\mathrm{PD}_{9} \mathrm{~B}$ (Tabel 2).

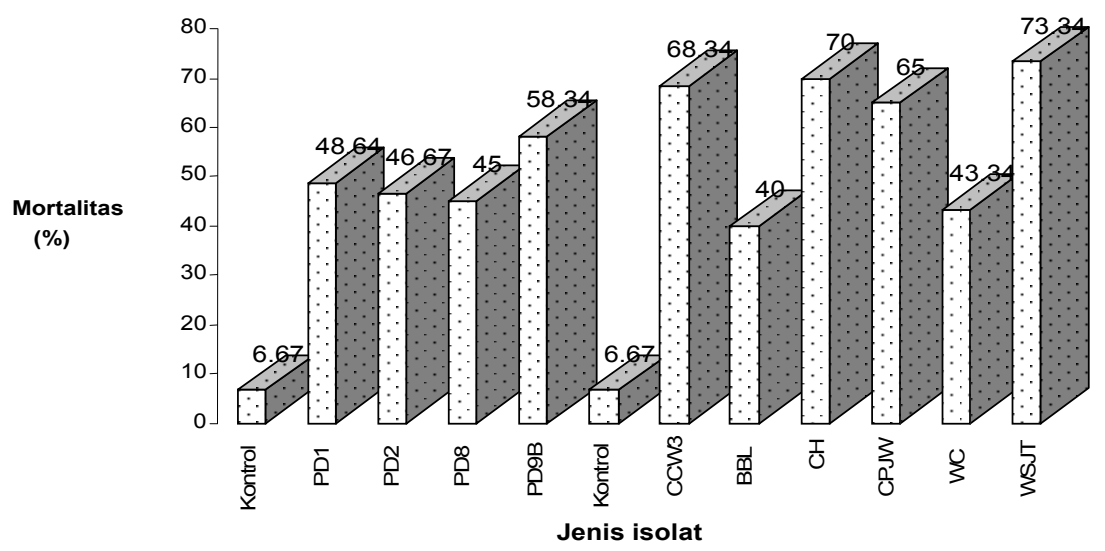

Gambar 2. Mortalitas larva Plutella xylostella L. pada perlakuan berbagai isolat Beauveria bassiana (Bals.) Vuill. 48 jam setelah aplikasi 
Perilaku Larva Plutella xylostella L. (sejak aplikasi hingga menjelang kematian)

Dari hasil pengamatan yang dilakukan setelah aplikasi B. Bassiana terhadap larva P. xylostella didapatkan bahwa setelah penetesan isolat cendawan ke tubuh larva uji, larva berhenti beraktivitas untuk beberapa saat (10-20 detik) tetapi setelah itu larva kembali beraktifitas yaitu mulai memakan daun caisin yang telah di sediakan. Larva $P$. xylostella yang telah terinfeksi oleh cendawan B. bassiana menunjukkan ciri yang khas pada tubuhnya. Warna tubuhnya berubah secara bertahap mulai dari hijau terang menjadi hijau tua kecoklatan. Pada saat itu, larva menjadi lemah tetapi tetap beraktifitas untuk makan. Tubuh larva yang hijau kecoklatan berubah menjadi kuning kecoklatan, kemudian berubah menjadi coklat kehitaman. Pada saat itu, aktifitas makan dan gerak larva telah berhenti total. Kemudian larva mati dan tubuhnya

Tabel 2. Nilai $\mathrm{LT}_{50}$ berbagai isolat Beauveria bassiana yang diujikan pada Plutella xylostella instar 3

\begin{tabular}{lccc}
\hline \hline \multirow{2}{*}{ Isolat } & $\begin{array}{c}\mathrm{LT}_{50} \\
(\mathrm{Jam})\end{array}$ & \multicolumn{2}{c}{ Selang Kepercayaan 95\% } \\
\cline { 3 - 4 } & 40.56 & 34.51 & Tertinggi \\
\hline $\mathrm{PD}_{1}{ }^{*}$ & 42.07 & 35.53 & 50.21 \\
$\mathrm{PD}_{2}{ }^{*}$ & 44.81 & 39.6 & 53.19 \\
$\mathrm{PD}_{8}{ }^{*}$ & 19.27 & 13.46 & 26.43 \\
$\mathrm{PD}_{9} \mathrm{~B}^{*}$ & 24.91 & 22.17 & 27.94 \\
$\mathrm{CCW}$ & 66.66 & 51.87 & 97.99 \\
$\mathrm{BBL}$ & 23.26 & 20.59 & 26.22 \\
$\mathrm{CH}$ & 26.96 & 23.37 & 31.4 \\
$\mathrm{CPJW}$ & 47.56 & 42.1 & 55.68 \\
WC & 24.2 & 21.72 & 26.87 \\
WSJT & &
\end{tabular}

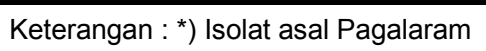

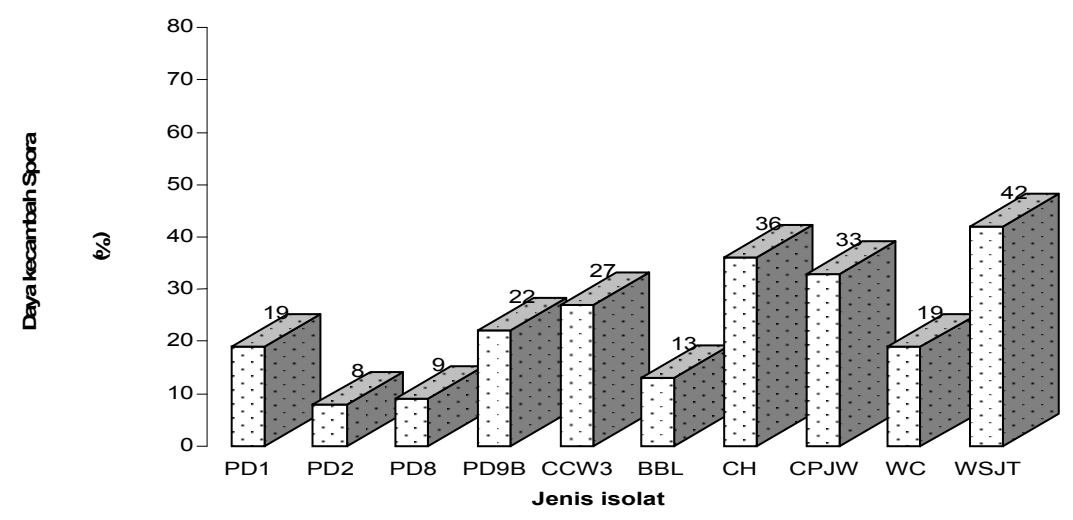

Gambar 3. Daya kecambah spora sebelum aplikasi (media beras setengah masak) setelah 24 jam pengamatan 
berubah menjadi hitam dan mengeras seperti mumi. Jika kondisi suhu dan kelembaban ruangan sesuai, maka pada tubuh serangga tersebut akan tumbuh hifa cendawan B. bassiana yang berwarna putih.

\section{Daya Kecambah Spora Masing-} masing Isolat Sebelum Aplikasi (pada media beras setengah masak) dan Sesudah Aplikasi (Glukosa Yeast Agar)

Sebelum dilakukan aplikasi
terhadap Plutella xylostella,

cendawan semua isolat diuji terlebih dahulu daya kecambahnya untuk menduga kemampuan penetrasinya. Hasil percobaan menunjukkan bahwa persentase viabilitas spora tertinggi terdapat pada isolat WSJT (42\%). Setelah 24 jam, persentase viabilitas spora terendah terdapat pada isolat BBL $(22 \%)$, tertinggi terdapat pada isolat WC $(58 \%)$.

Tabel 3. Kerapatan spora Beauveria bassiana pada media beras setengah masak dan media GYA

\begin{tabular}{lccc}
\hline \hline No & Isolat & \multicolumn{2}{c}{ Kerapatan spora (spora/ml) } \\
\cline { 2 - 4 } & & $\begin{array}{c}\text { Sebelum aplikasi } \\
\text { (Media beras) }\end{array}$ & $\begin{array}{c}\text { Setelah Aplikasi } \\
\text { (Media GYA) }\end{array}$ \\
\hline 1 & $\mathrm{PD}_{1}$ & $4.2 \times 10^{6}$ & $1.7 \times 10^{7}$ \\
2 & $\mathrm{PD}_{2}$ & $4.2 \times 10^{6}$ & $1.6 \times 10^{7}$ \\
3 & $\mathrm{PD}_{8}$ & $9.7 \times 10^{6}$ & $1.3 \times 10^{7}$ \\
4 & $\mathrm{PD}_{9}$ & $2.2 \times 10^{7}$ & $3.0 \times 10^{7}$ \\
5 & $\mathrm{CCW}_{3}$ & $4.5 \times 10^{7}$ & $3.0 \times 10^{7}$ \\
6 & $\mathrm{BBL}$ & $1.1 \times 10^{7}$ & $3.0 \times 10^{7}$ \\
7 & $\mathrm{CH}$ & $5.0 \times 10^{7}$ & $2.8 \times 10^{7}$ \\
8 & $\mathrm{CPJW}$ & $2.1 \times 10^{7}$ & $3.0 \times 10^{7}$ \\
9 & $\mathrm{WC}$ & $1.8 \times 10^{7}$ & $9.2 \times 10^{6}$ \\
10 & $\mathrm{WSJT}$ & $5.6 \times 10^{7}$ & $3.0 \times 10^{7}$ \\
\hline
\end{tabular}

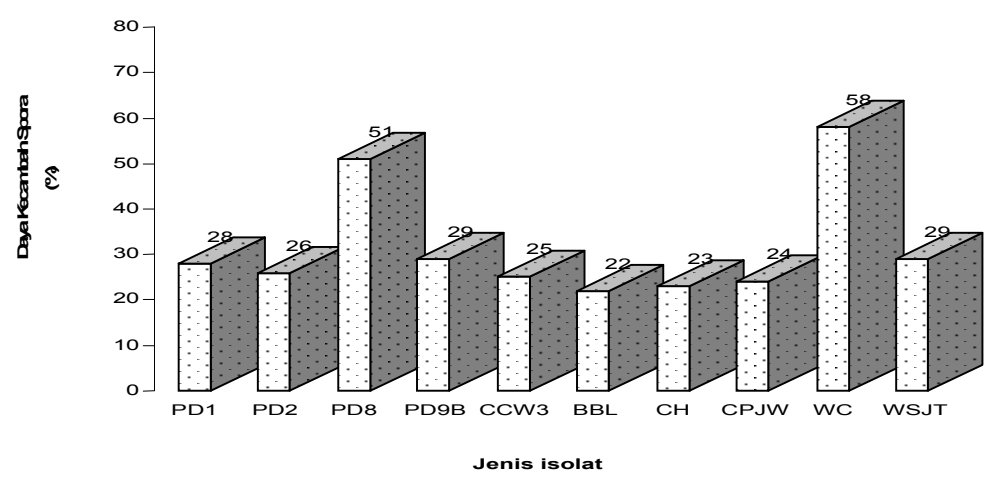

Gambar 4. Daya kecambah spora setelah aplikasi (media GYA) setelah 24 jam pengamatan 
Kerapatan Spora Sebelum Aplikasi (pada media beras setengah masak) dan Sesudah Aplikasi (pada Media GYA)

Perbedaan kerapatan spora antara masing-masing isolat dapat dilihat pada Tabel 3. Dari tabel tersebut terlihat bahwa kerapatan spora sebelum aplikasi (pada media beras setengah masak)

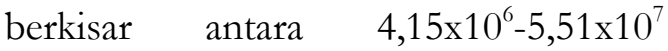
spora/ml. sedangkan kerapatan spora setelah aplikasi (pada media GYA)

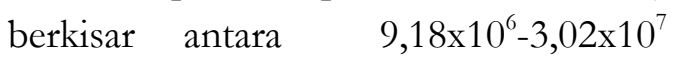
spora/ml. Beberapa isolat mengalami kenaikan dan penurunan jumlah kerapatan spora. Isolat yang mengalami kenaikan jumlah kerapatan spora adalah $\mathrm{PD}_{1}, \mathrm{PD}_{2}, \mathrm{PD}_{8}, \mathrm{PD}_{9} \mathrm{~B}, \mathrm{BBL}, \mathrm{CPJW}$. sebaliknya isolat $\mathrm{CCW}_{3}, \mathrm{CH}$, WC, WSJT mengalami penurunan jumlah kerapatan spora.

Isolat WSJT (isolate non Pagaralam, asal inokulum $L$. acuta) merupakan isolat yang terbaik dari seluruh isolat yang digunakan karena mampu membunuh larva P. xylostella hingga $73,34 \%$ dalam kurun waktu 48 jam. Isolat $\mathrm{PD}_{9} \mathrm{~B}$ merupakan isolat yang terbaik yang berasal dari Pagaralam karena mampu membunuh larva $P$. xylostella hingga mencapai 58,34 persen selama 48 jam.

Dari hasil pengamatan diketahui bahwa larva yang terinfeksi cendawan $B$. bassiana menunjukkan gejala berupa gerakan yang melambat, dan aktivitas makan yang berkurang. Larva kemudian diam tidak bergerak dan akhirnya mati.
Pada fase tersebut tubuh larva berubah warna mulai dari hijau muda menjadi hijau tua, kemudian kuning kecoklatan, coklat kehitaman dan akhirnya menjadi hitam. Hal ini sesuai dengan pernyataan Mahr (2003) bahwa akibat serangan $B$. bassiana ulat menjadi tidak aktif bergerak daya makannya berkurang. Tubuhnya membengkak dan akhirnya timbul bercak kehitaman dan akhirnya menjadi mumi.

Daya kecambah spora (viabilitas) antara jamur pada media beras setengah masak (sebelum aplikasi) dengan pada media GYA (setelah aplikasi) sangat bervariasi. Viabilitas spora pada media beras setengah masak jauh lebih rendah dibandingkan dengan viabilitas pada media GYA. Hal ini sangat dipengaruhi oleh keadaan nutrisi yang terkandung di masing-masing media. Hal ini sesuai dengan pernyataan Ferron (1980 dalam Sudarmadji 1994) bahwa sumber nutrisi dapat mempengaruhi pertumbuhan cendawan entomopatogen. Dua isolat yang mempunyai daya kecambah spora terbaik pada media beras setengah masak adalah WSJT dan CH (Gambar 3) Gambar 4 menunjukkan bahwa 2 isolat yang mempunyai daya kecambah spora terbaik pada media GYA adalah WC (Bogor) dan $\mathrm{PD}_{8}$.

Selain dipengaruhi oleh bahan media yang digunakan, daya kecambah dan pertumbuhan spora juga sangat dipengaruhi oleh suhu dan kelembaban udara setempat. Menurut Wasted et al. (1970 dalam Junianto dan Sukamto 
1995), perkecambahan, pertumbuhan dan sporulasi optimum cendawan $B$. bassiana terjadi pada suhu $25-30^{\circ} \mathrm{C}$ dan kelembaban relatif $100 \%$. Suhu rata-rata selama penelitian berkisar antara $27-31^{0}$ $\mathrm{C}$ dan $25,5-29^{\circ} \mathrm{C}$.

Kerapatan spora yang berbedabeda antara isolat yang satu dengan yang lain dipengaruhi oleh nutrisi yang terkandung dalam masing-masing media. Nutrisi yang sangat dibutuhkan oleh cendawan B. bassiana untuk tumbuh cukup tersedia dimedia GYA sebagai media yang digunakan setelah aplikasi. Pada saat aplikasi, cendawan B. bassiana mendapat nutrisi langsung dari ulat $P$. xylostella yang masih hidup. Cairan tubuh larva yang mengandung nutrisi yang cukup tinggi habis digunakan oleh cendawan B. bassiana, sehingga dapat tumbuh dengan baik di dalam maupun di luar tubuh larva. Cendawan B. bassiana yang tumbuh dengan baik pada tubuh larva kemudian ditanam ke media GYA. Cendawan B. bassiana yang sebelumnya telah tumbuh dengan baik diberi nutrisi pelengkap yang tidak terdapat di cairan tubuh larva sehingga tumbuh menjadi jauh lebih baik lagi dari sebelumnya.

Seperti halnya dengan viabilitas, kerapatan spora juga dipengaruhi oleh perbedaan jenis media. Pada media beras setengah masak, kerapatan sporanya relatif lebih rendah jika dibandingkan dengan pada media GYA. Hal ini dipengaruhi oleh komposisi nutrisi terkandung dikedua media. Pada media beras setengah masak terdapat protein dan karbohidrat yang cukup dominan sedangkan pada media GYA komposisi yang terkandung cukup merata tetapi beragam diantaranya yaitu karbohidrat, protein, glukosa dan kitin. Oleh sebab itu, kerapatan spora pada media GYA lebih tinggi dari pada kerapatan spora pada media beras setengah masak.

\section{KESIMPULAN}

Isolat B. bassiana asal daerah Pagaralam Sumatera Selatan yang mampu membunuh ulat Plutella xylostella paling cepat adalah isolat $\mathrm{PD}_{9} \mathrm{~B}\left(\mathrm{LT}_{50}=\right.$ 19,27 jam). B. bassiana isolat WSJT (isolat non Pagalaram) mampu mematikan larva Plutella sebesar 73,34 persen pada pengamatan 48 jam setelah aplikasi. Daya kecambah spora B. bassiana pada media beras setengah masak adalah sebesar 42\%. Nilai kerapatan spora tertinggi pada media beras setengah masak dan pada media GYA berturutturut adalah $5,6 \times 10^{7}$ spora $/ \mathrm{ml} 3,0 \times 10^{7}$ spora $/ \mathrm{ml}$.

\section{DAFTAR PUSTAKA}

Andrahennadi R, C. Gillot. 1998. Resistence of Brassica, Especially Brassica juncea (L) Czern, Genotypes to The Diamondback moth, Plutella xylostella. Departement of Biology, University of Saskatchewan, Canada S7N 5E 2 (htpp://www. Elsevier.com/locate/cropro, diakses 12 Pebuari 1998).

Charleston SD, R Kfir. 2000. The Possibility of using Indian mustard Brassica juncea as trap crof for diamondback moth Plutella xylostella, in South Africa. Crop Protection 19: 455-460. 
Cloyd. 2003. Nursery, Greenhouse and Landscape: Naturalis-O, A new Mycoinsecticida.

htpp://www.Entomology.wisc.edu/mben Lland210html) (diakses 21 Januari 2003).

Junianto YD, S Sukamto. 1995. Pengaruh Suhu dan Kelembaban Relatif terhadap Perkecambahan, Pertumbuhan dan Sporulasi bebrapa Isolat Beauveria bassiana. Jurnal Pelita Perkebunan 11(2): 64-75.

Mahr, S. 2003. Know your friends. The entomopathogen Beauveria bassiana (htpp://www.entomology.wisc.edu/mbcn /kyf410html. Diakses 21 Januari 2003).

Oka I. 1998. Pengendalian Hama Terpadu dan Implementasinya di Indonesia. Yogyakarta: Gadjah Mada University Press. .

Pujiastuti, Y. 2004. Eksplorasi dan Identifikasi patogensitas indigenous entomopatogen dalam pengembangan PHT terhadap Plutella xylostella (Lepidoptera: Yponomeutidae) pada sayuran Brassicaceae. [Laporan Penelitian Dasar]. Jakarta: DIKTI.
Rasminah S, S. Santoso, Y. Ratna. 1997. Kajian Kualitas Spora Beauveria bassiana pada Berbagai Jenis Media (PDA, Jagung, Alioshina) dan Lama Penyimpanan. Prosiding Kongres Nasional XIV dan Seminar Ilmiah Perhimpunan Fitopatologi Indonesia. Palembang. 27-29 Oktober 1997.

STBPTPH V (Satuan Tugas Balai Proteksi Tanaman Pangan dan Hortikultura). 1998. Pengendalian Walang Sangit dengan Cendawan Beauveria bassiana. Yogyakarta. 3 hal.

Sudarmadji D.1994. Penetapan TingkatVirulensi Empat Isolat Beauveria bassiana (Balsamo) Vuillemin. Terhadap Helopeltis antonii Sign. Jurnal Menara Perkebunan. 62: 47-51.

Ulmer B, C Gillott, D. Woods, M Erlandson. 2001. Diamondback moth, Plutella xylostella (L) feeding and oviposition preferences on glossy and waxy Brassica rapa (L) lines. Crop Protection 21: 327-331. 